\title{
Survei Penggunaan Tensorflow pada Machine Learning untuk Identifikasi Ikan Kawasan Lahan Basah
}

\author{
Nuruddin Wiranda*1, Harja Santana Purba ${ }^{2}$, R Ati Sukmawati ${ }^{3}$ \\ ${ }^{1,2,3}$ Prodi Pendidikan Komputer, FKIP, Universitas Lambung Mangkurat, Indonesia \\ e-mail: *11 nuruddin.wd@ulm.ac.id, ${ }^{2}$ harja.sp@ulm.ac.id, ${ }^{3}$ atisukmawati@ulm.ac.id
}

\begin{abstract}
Abstrak
Lahan basah merupakan habitat yang biasanya digunakan untuk budidaya ikan. Kalimantan Selatan termasuk salah satu provinsi yang memiliki kawasan lahan basah, yaitu seluas 11.707.400ha, terdapat 67 buah sungai dan ditaksir terdapat 200-an jenis ikan. Hal ini menunjukkan kekayaan khazanah ikan yang melimpah, dan bernilai ekonomis. Studi tentang identifikasi ikan merupakan subjek yang penting untuk konservasi khazanah ikan lahan basah. Dalam bidang kecerdasan buatan, identifikasi dapat dilakukan menggunakan Machine Learning (ML). Terdapat banyak librari, kumpulan fungsi yang dapat digunakan dalam pengembangan ML, salah satunya adalah Tensorflow. Dalam makalah ini, kami mensurvei beragam literatur tentang penggunaan Tensorflow, serta dataset, algortima dan metode yang dapat digunakan dalam pengembangan aplikasi identifikasi citra ikan kawasan lahan basah.

Hasil survei literatur menunjukan bahwa Tensorflow dapat digunakan untuk pengembangan aplikasi identifikasi cirta ikan. Terdapat banyak dataset yang dapat digunakan seperti MNIST, Oxford-I7, Oxford-102, LHI-Animal-Faces, Taiwan marine fish, KTH-Animal, NASNet, ResNet, dan MobileNet. Metode klasifikasi yang dapat digunakan untuk klasifikasi citra ikan diantaranya adalah $C N N, R-C N N, D C N N$, Fast $R-C N N, k N N, P N N$, Faster R-CNN, $S V M, L R, R F, P C A$ dan KFA. Tensorflow menyediakan banyak model yang dapat digunakan untuk klasifikasi citra diantaranya adalah Inception-v3 dan MobileNets, serta mendukung pemodelan seperti $C N N, R N N, R B M$, dan DBN. Untuk mempercepat proses klasifikasi, dimensi citra dapat dikurangi menggunakan algoritma MDS, LLE, Isomap dan SE.
\end{abstract}

Kata kunci-Machine Learning, Identifikasi Citra, Tensorflow, Citra ikan lahan basah

Abstract
Wetlands are habitats commonly used for fish cultivation. South Kalimantan is one of the provinces that has a wetland area, which is 11,707,400ha, there are 67 rivers and an estimated 200 species of fish. This shows the abundant wealth of fish treasures and economic value. The study of fish identification is an important subject for the preservation of wetland fish. In the field of artificial intelligence, identification can be done using Machine Learning $(M L)$. There are many libraries, a collection of functions that can be used in ML development, one of which is Tensorflow. In this paper, we survey a variety of literature on the use of Tensorflow, as well as datasets, algorithms, and methods that can be used in developing wetland area fish image identification applications.

The results of the literature survey show that Tensorflow can be used for the development of fish character identification applications. There are many datasets that can be used such as MNIST, Oxford-I7, Oxford-102, LHI-Animal-Faces, Taiwan marine fish, KTHAnimal, NASNet, ResNet, and MobileNet. Classification methods that can be used to classify fish images include CNN, R-CNN, DCNN, Fast R-CNN, kNN, PNN, Faster R-CNN, SVM, LR, $R F, P C A$ and KFA. Tensorflow provides many models that can be used for image classification, including Inception-v3 and MobileNets, and supports models such as CNN, RNN, RBM, and $D B N$. To speed up the classification process, image dimensions can be reduced using the MDS, LLE, Isomap, and SE algorithms.

Keywords - Machine Learning, Image Identification, Tensorflow, Image of Wetland Fish. 


\section{PENDAHULUAN}

Kalimantan Selatan(Kalsel) memiliki luas wilayah $37.530,52 \mathrm{~km} 2$ atau sama dengan 6,98\% dari luas Pulau Kalimantan, yang mana 3.580.500ha merupakan lahan basah lebak, dan 8.126.900ha lahan basah pasang surut [1]. Lahan basah merupakan daerah rawa, berlahan gambut, payau, dan perairan. Lahan basah merupakan habitat yang biasanya digunakan untuk budidaya ikan [2]. Kalsel memiliki 67 buah sungai, salah satunya adalah Sungai Barito. Banyaknya sungai di Kalsel menunjukkan bahwa sangat berpotensi untuk membangun wilayahnya dari sektor perikanan. Setidaknya terdapat 200 -an jenis ikan di Kalsel, yang mana 101 jenis ikannya dapat ditemukan pada perairan Sungai Barito, seperti Adungan, Baga baga, Bakut, Baung, Biawan, Bilis, Bujuk, Buntal, Haruan, Kelabau, Lais, Karangdang, Kahung, Lawang, Puyau, Riu-riu, Tilan, Toman, Kupak dan masih banyak lagi [1]. Selain Sungai Barito terdapat juga Sungai Sambujur yang merupakan anak Sungai Barito, disana dapat ditemukan 73 jenis ikan [3], seperti Papuyuh, Tabiring, Bunggut, Sanggang, Jono, Tilan dan masih banyak lagi. Hal ini menunjukan betapa kayanya khazanah ikan sungai di Kalsel. Kemelimpahan ikan ini memiliki nilai ekonomis tersendiri bagi Kalsel. Namun masih banyak jenis ikan yang belum diteliti, dideskripsikan [1], dan teridentifikasi, serta masih banyak juga masyarakat yang belum mengenal jenis-jenis ikan tersebut.

Era modern yang penuh dengan data seperti sekarang ini, banyak bermunculan sistem cerdas yang dapat mempermudah manusia dalam beraktifitas teruma dalam penggunaan teknologi. Ketika pengguna mengetikan kata kunci pada mesin pencari, dengan cepat bahkan sebelum pengguna selesai mengetikan kata kunci, mesin pencari telah selesai memberikan apa yang pengguna inginkan secara akurat. Ketika pengguna mengunggah foto pada media sosial, secara otomatis dan cepat media sosial melakukan deteksi wajah-wajah yang terdapat pada foto tersebut. Semua kemampuan tersebut merupakan beberapa contoh terapan dari teknik kecerdasan buatan, khususnya Machine Learning (ML). ML dapat menjadi salah satu solusi dalam permasalah yang terjadi pada kebun binatang, yaitu ketika pengunjung memasuki kebun binatang, pengunjung hanya perlu menggunakan kamera smartphone untuk menfoto, dan secara otomatis sistem akan mengenali nama dan deskripsi dari hewan tersebut. Solusi ini memungkinkan pengunjung untuk membaca deskripsi dari hewan tersebut di waktu yang bersamaan, tanpa harus mengantri untuk membaca label yang tertera di kandang hewan.

ML adalah bidang penelitian interdisipliner menggabungkan ide-ide dari beberapa cabang ilmu yaitu, kecerdasan buatan, statistik, teori informasi, matematika, dan lain lain. Fokus utama penelitian ML adalah pada pengembangan algoritma pembelajaran yang cepat dan efisien untuk membuat prediksi pada data. Saat berurusan dengan analisis data, ML merupakan pendekatan yang digunakan untuk membuat model untuk prediksi [4]. Pengembangan aplikasi ML dapat dilakukan menggunakan librari, seperti Tensorflow, Caffe, Theano, Torch, dan Keras. Menurut Parvat [5], Tensorflow merupakan librari open source yang sangat fleksibel karena lebih dari sekadar framework. Berdasarkan uraian diatas, tujuan dari makalah penelitian ini adalah untuk melakukan survei literatur penggunaan Tensorflow sebagai librari ML, serta menggali infromasi terkait dataset, algoritma dan metode yang dapat digunakan dalam pengembangan aplikasi identifikasi citra ikan kawasan lahan basah.

\section{METODE PENELITIAN}

Survei literatur ini terdiri dalam 3 tahapan utama yaitu mencari, meninjau dan menulis tinjauan literatur[12]. Dalam tahapan mencari literatur, dilakukan pencarian makalah ilmiah tentang tensorflow, ML, dataset yang digunakan, metode klasifikasi, dan hasil yang diperoleh oleh peneliti terdahulu. Dalam tahapan peninjauan dilakukan peninjauan terhadap literature dari hasil pencarian. Tahapan terakhir yaitu melakukan penulisan dari hasil temuan dari berbagai literatur. Literatur yang digunakan sebanyak 16 judul yang terbit pada rentang tahun 2015 sampai 2020.

IJEIS Vol. 10, No. 2, October 2020 : $179-188$ 


\section{HASIL DAN PEMBAHASAN}

\subsection{Survei Literatur}

Yuan dkk. [13] melakukan penelitian tentang pengenalan citra wajah menggunakan metode CNN dengan memanfaatkan librari TensorFlow. Eksperimen Yuan dkk. [13] menunjukkan bahwa normalisasi dapat mengurangi dimensi data, secara efektif mengurangi waktu pelatihan dan meningkatkan tingkat pengenalan. Metode CNN menghasilkan akurasi pengenalan wajah yang lebih baik dan ketahanan yang lebih tinggi di lingkungan yang kompleks dibandingkan dengan fitur hand-crafted tradisional [13]. Selain pengenalan wajah, Tensorflow juga bisa digunakan untuk aplikasi pengenalan benda/objek lainnya, seperti yang dilakukan oleh Mulfari dkk. [14], yaitu mengembangkan aplikasi mobile untuk mengeksplorasi warisan arsitek yang terdapat di musium. Aplikasi tersebut memanfaatkan kamera smartphone untuk mengenali objek yang ada pada musium (seperti bangunan bersejarah, patung, monumen, lukisan) dengan hasil akurasi yang baik. Islam dkk. [11] menyatakan bahwa CNN bekerja sangat baik dalam klasifikasi.

Penelitian yang dilakukan oleh Ertam [15] menggunakan dataset MNIST dan library Tensorflow untuk melakukan klasifikasi. MNIST adalah sebuah singkatan dari "Modified National Institute of Standards and Technology " dan merupakan kumpulan Big Data yang terdiri dari angka tulisan tangan yang banyak digunakan untuk pelatihan sistem pemrosesan gambar. Ertam [15] menggunakan berbagai fungsi aktivasi dalam proses klasifikasi sistem, diantaranya adalah fungsi aktivasi Rectified Linear Unit (ReLu), Hyperbolic Tangent $(\tan \mathrm{H})$, Unit Linear Eksponensial (eLu), sigmoid, softplus dan softsign. SoftMax digunakan sebagai fungsi classifier. Berdasarkan hasil ekperimen diperoleh bahwa akurasi terbaik dicapai ketika menggunakan fungsi aktivasi ReLu, yaitu sebesar 98,43\% [15] .

Xia dkk. [16] melakukan penelitian menggunakan model Inception-v3 TensorFlow untuk mengklasifikasi bunga. Model Inception-v3 merupakan CNN yang telah dilatih menggunakan lebih dari satu juta citra dari basis data ImageNet. Model Inception-v3 dapat mengklasifikasikan gambar ke dalam 1.000 kategori objek, seperti keyboard, mouse, pensil, bunga, burung, ikan dan lain-lain. Hasil akurasi dari klasifikasi model tersebut sebesar adalah 95\% saat menggunakan dataset bunga Oxford-I7 dan 94\% pada dataset bunga Oxford-102. Gavai dkk. [17] juga melakukan hal serupa, namun menggunakan model yang berbeda yaitu MobileNets. Hasil yang diperoleh menunjukan bahwa model MobileNets dapat mengoptimalkan waktu dan ruang (walaupun mengorbankan akurasi) dibandingkan menggunakan model Inception-v3.

Penelitian yang dilakukan Cao dkk. [18] tentang klasifikasi hewan laut menggunakan gabungan metode CNN dan Fitur Hand-designed pada dataset ikan laut Taiwan yang terdiri dari 23 jenis ikan dan total 27.370 contoh ikan. Dimensi fitur adalah 4.096 untuk CNN dan 2.626 untuk fitur Hand-designed. Hasil yang diperoleh dengan menggunakan CNN saja memberikan klasifikasi yang memuaskan, sedangkan menggunakan Hand-designed saja memberikan ketahanan ketika kualitas gambar diturunkan. Hasil dari penggabungan kedua fitur tersebut memberikan pengetahuan fitur yang saling melengkapi, membantu mengurangi dimensi fitur tanpa mengurangi kinerja klasifikasi [18].

Selain menggunakan CNN, metode K-Nearest Neighbors (KNN) dan Probabilistic Neural Network (PNN) juga bisa digunakan [19]. Taheri dan Toygar [20] melakukan penelitian serupa namun dengan pendekatan yang berbeda menggunakan score-level fusion. Dataset yang digunakan adalah LHI-Animal-Faces yang berisi 19 kelas citra kepala hewan ditambah satu kelas citra kepala manusia dengan jumlah keseluruhan 2.200 citra. Metode yang digunakan [20] adalah CNN dan Kernel Fisher Analysis (KFA). Dari hasil percobaan menggunakan CNN (FC7 VGG-16 features) menghasilkan akurasi $92.84 \%$, hal ini menunjukan bahwa CNN lebih baik daripada teknik ekstraksi fitur sederhana lainnya (baik fitur berbasis local maupun fitur tampilan seperti LDA, KFA). Selain itu juga dilakukan klasifikasi menggunakan gabungan metode CNN dan KFA, menghasilkan akurasi yang lebih besar, yaitu $95.31 \%$.

Faaeq [21] melakukan Klasifikasi citra ikan menggunakan Manifold Learning pada dataset KTH-animal yang terdiri dari 1.740 citra di 19 kelas hewan yang berbeda. Selain itu 
juga menggunakan model Inception-v3 Google dengan 2.048 node. Metode klasifikasi yang digunakan adalah SVM, Logistic Regression (LR), Random Forest (RF) dan kNN. Untuk mengurangi dimensi citra digunakan 4 Manifold Learning yaitu Locally Linear Embedding (LLE), Spectral Embedding (SE), Multi dimensional scaling (MDS), dan Isomap. Hasil menunjukan bahwa penerapan manifold learning dengan menerapkan algoritma pengurangan dimensi citra sebelum klasifikasi dapat secara signifikan meningkatkan kecepatan klasifikasi dengan tingkat akurasi yang tinggi. Berdasarkan statistik percobaan, menunjukkan bahwa saat menggunakan Isomap lalu diklasifikasi menggunakan $\mathrm{kNN}$ diperoleh hasil terbaik dan dapat mengurangi waktu eksekusi dari 45,695 detik menjadi 0,434 detik.

Dandil dan Polattimur [22] melakukan pengembangan sistem berbasis biometrik untuk klasifikasi spesies hewan dengan Principal Component Analysis (PCA). Spesies yang diklasifikasi adalah sapi, kucing, anjing, kambing dan kelinci. Berdasarkan uji coba pertama didapatkan rata-rata akurasi sebesar 92\%. Dalam penelitian Manohar dkk. [23] tentang klasifikasi berbasis supervised dan unsupervised untuk mengklasifikasikan hewan. Tahap pertama citra hewan disegmentasi menggunakan algoritma segmentasi. Selanjutnya citra yang telah disegmentasi, diekstrasi menggunakan metode Gabor features. Linear Discriminate Analysis (LDA) salah satu teknik untuk mengurangi dimensi citra digunakan untuk mengurangi fitur. Fitur yang telah diperkecil dimasukkan ke dalam klasifikasi simbolik untuk tujuan klasifikasi. Dari eksperimen menggunakan dataset 2.000 citra hewan yang terdiri dari 20 kategori hewan yang berbeda menunjukan hasil bahwa sistem klasifikasi menggunakan supervised berperforma lebih baik dibandingkan dengan metode unsupervised [23]. Gomez dkk. [24] menggunakan metode Deep Convolutional Neural Networks (DCNN) untuk pengenalan spesies hewan, menghasilkan akurasi $88,9 \%$ pada Top-1 dan $98.1 \%$ pada Top-5 saat menggunakan dataset 26 spesies yang sudah stabil. Block dkk. [25] menggunakan R-CNN untuk mengidentifikasi spesies ular. Dataset yang digunakan adalah Snake CLEF dan AICrowd Snake. Hasil yang diperoleh menunjukan peningkatan skor rata-rata F1 makro menjadi 0,594 yang sebelumnya bernilai 0,404. Monkman dkk. [26] menggunakan metode R-CNN untuk mengestimasi ukuran ikan fusiform. Dataset yang digunakan adalah NASNet, ResNet, dan MobileNet. Hasil akurasi yang diperoleh sebesar 93\%. Pada penelitian Mahavarkar dkk. [27] dan Karthikeyan dkk. [28] dalam pengenalan objek underwater, masing-masing memperoleh hasil akurasi yang baik yaitu 96,21\% dan 98,9\% dengan menggunakan metode yang berbeda yaitu metode Faster R-CNN [27] dan DCNN [28]. Rangkuman dari penelitian yang telah dibahas diatas telah disajikan pada Tabel 1.

Tabel 1. Ringkasan Survei Literatur

\begin{tabular}{|c|c|l|l|}
\hline No & Penulis & $\begin{array}{l}\text { Algoritma / Metode / } \\
\text { Librari / Objek / Dataset }\end{array}$ & \multicolumn{1}{c|}{ Ringkasan } \\
\hline 1 & {$[13]$} & $\begin{array}{l}\text { CNN, Tensorflow, fitur } \\
\text { hand-crafted, Pengenalan } \\
\text { wajah }\end{array}$ & $\begin{array}{l}\text { Membuat aplikasi pengenalan wajah } \\
\text { menggunakan metode CNN. Hasil menunjukkan } \\
\text { metode CNN memiliki akurasi pengenalan yang } \\
\text { lebih baik dan ketahanan yang lebih tinggi di } \\
\text { lingkungan yang kompleks dibandingkan } \\
\text { dengan fitur hand-crafted. }\end{array}$ \\
\hline 2 & {$[14]$} & $\begin{array}{l}\text { CNN, Tensorflow, } \\
\text { Pengenalan objek di } \\
\text { musium }\end{array}$ & $\begin{array}{l}\text { Tensorflow digunakan untuk mengenali objek } \\
\text { (bangunan bersejarah, patung, monumen, } \\
\text { lukisan) dengan hasil akurasi yang baik. }\end{array}$ \\
\hline 3 & {$[15]$} & $\begin{array}{l}\text { Fungsi aktivasi ReLu, } \\
\text { tanH,eLu, sigmoid, } \\
\text { softplus, softsign; }\end{array}$ & $\begin{array}{l}\text { Melakukan klasifikasi dataset MNIST } \\
\text { menggunakan fungsi aktivasi yang berbeda. } \\
\text { Hasil menunjukan bahwa fungsi ReLu memiliki }\end{array}$ \\
\hline
\end{tabular}

IJEIS Vol. 10, No. 2, October 2020 : $179-188$ 


\begin{tabular}{|c|c|c|c|}
\hline & & $\begin{array}{l}\text { SoftMax; Tensorflow; } \\
\text { MNIST, Klasifikasi citra } \\
\text { angka }\end{array}$ & akurasi terbaik, yaitu 98,43\%. \\
\hline 4 & [16] & $\begin{array}{l}\text { Inception-v3, TensorFlow, } \\
\text { dataset Oxford-I7, } \\
\text { Oxford-102, , Klasifikasi } \\
\text { citra bunga }\end{array}$ & $\begin{array}{l}\text { Melakukan klasifikasi bunga menggunakan } \\
\text { model Inception-v3. Hasil akurasi } 95 \% \text { untuk } \\
\text { dataset flower Oxford-I7 dan } 94 \% \text { untuk dataset } \\
\text { Oxford-102. }\end{array}$ \\
\hline 5 & [17] & $\begin{array}{l}\text { Model Inception-v3, } \\
\text { Model MobileNets, } \\
\text { Tensorflow, Klasifikasi } \\
\text { citra bunga }\end{array}$ & $\begin{array}{l}\text { Menguji model MobileNets untuk } \\
\text { mengklasifikasikan bunga. Hasil menunjukan } \\
\text { model MobileNets lebih optimal dibandingkan } \\
\text { Inception-v3. }\end{array}$ \\
\hline 6 & [18] & $\begin{array}{l}\text { CNN, Hand-designed, } \\
\text { Citra ikan laut }\end{array}$ & $\begin{array}{l}\text { Melakukan klasifikasi ikan menggunakan } \\
\text { perpaduan CNN dan Hand-designed. Hasil } \\
\text { penggabungan kedua fitur tersebut dapat } \\
\text { mengurangi dimensi fitur tanpa mengurangi } \\
\text { kinerja klasifikasi. }\end{array}$ \\
\hline 7 & [19] & $\begin{array}{l}\text { PPN, kNN, Klasifikasi } \\
\text { hewan }\end{array}$ & $\begin{array}{l}\text { Menggunakan } 25 \text { kelas yang terdiri dari } 4.000 \\
\text { sampel, hasil menunjukkan akurasi kNN lebih } \\
\text { baik daripada PNN. }\end{array}$ \\
\hline 8 & [20] & $\begin{array}{l}\text { CNN, KFA, score-level } \\
\text { fusion, Dataset LHI- } \\
\text { Animal-Faces }\end{array}$ & $\begin{array}{l}\text { Melakukan klasifikasi wajah hewan pada dataset } \\
\text { LHI-Animal-Face menggunakan metode CNN } \\
\text { dan KFA. Hasil penggabungan metode CNN dan } \\
\text { KFA menghasilkan akurasi yang sangat baik, } \\
\text { yaitu } 95.31 \% \text {. }\end{array}$ \\
\hline 9 & [21] & $\begin{array}{l}\text { Manifold Learning (MDS, } \\
\text { LLE, Isomap dan SE); } \\
\text { Metode SVM, LR, RF, } \\
\text { kNN; Klasifikasi hewan, } \\
\text { dataset KTH-animal. }\end{array}$ & $\begin{array}{l}\text { Melakukan klasifikasi hewan menggunakan } \\
\text { Manifold Learning. Dataset terdiri dari } 1.740 \\
\text { citra di } 19 \text { kelas hewan. Metode Isomap pada } \\
\text { kNN menghasilkan akurasi terbaik dari pada } \\
\text { metode lainnya yang ada pada penelitian ini. }\end{array}$ \\
\hline 10 & {$[22]$} & $\begin{array}{l}\text { PCA, klasifikasi spesies } \\
\text { hewan (sapi, kucing, } \\
\text { anjing, kambing, kelinci) }\end{array}$ & $\begin{array}{l}\text { Melakukan klasifikasi spesies hewan } \\
\text { menggunakan metode PCA. Hasil akurasi } \\
\text { sebesar } 92 \% \text {. }\end{array}$ \\
\hline 11 & [23] & $\begin{array}{l}\text { Supervised dan } \\
\text { unsupervised, LDA, } \\
\text { Gabor features, Klasifikasi } \\
\text { hewan }\end{array}$ & $\begin{array}{l}\text { Melakukan klasifikasi menggunakan metode } \\
\text { supervised dan unsupervised menggunakan } \\
2.000 \text { citra hewan yang terdiri dari } 20 \text { kategori. } \\
\text { Hasil pengujian menunjukan bahwa supervised } \\
\text { memiliki performa lebih baik. }\end{array}$ \\
\hline 12 & [24] & $\begin{array}{l}\text { DCNN, pengenalan } \\
\text { spesies hewan }\end{array}$ & $\begin{array}{l}\text { Melakukan pengenalan spesies hewan } \\
\text { menggunakan DCNN, Hasil akurasi } 88,9 \% \text { pada } \\
\text { top-1 dan } 98.1 \% \text { pada top-5. }\end{array}$ \\
\hline 13 & [25] & $\begin{array}{l}\text { Keras, Tensorflow, } \\
\text { Region-based } \\
\text { Convolutional Neural } \\
\text { Network (R-CNN), }\end{array}$ & $\begin{array}{l}\text { Melakukan identifikasi spesies ular } \\
\text { menggunakan kombinasi informasi citra dan } \\
\text { lokasi dengan dataset snake CLEF dan AICrowd } \\
\text { Snake. Tool/teknologi yang digunakan python, }\end{array}$ \\
\hline
\end{tabular}




\begin{tabular}{|c|c|l|l|}
\hline & & $\begin{array}{l}\text { Dataset Snake CLEF dan } \\
\text { AICrowd Snake, } \\
\text { identifikasi spesies ular }\end{array}$ & $\begin{array}{l}\text { keras dan tensorflow. Pengenalan objek } \\
\text { menggunakan R-CNN, CNN, dan RPN. Setelah } \\
\text { dilakukan kombinasi rata-rata skor F1 mikro } \\
\text { meningkat menjadi 0,594. }\end{array}$ \\
\hline 14 & {$[26]$} & $\begin{array}{l}\text { R-CNN, OpenCV, } \\
\text { Tensorflow, Estimasi } \\
\text { Panjang ikan, NASNet, } \\
\text { ResNet, \& MobileNet. }\end{array}$ & $\begin{array}{l}\text { Mengestimasi Panjang ikan fusiform dilakukan } \\
\text { menggunakan R-CNN dengan librari tensorflow } \\
\text { Dataset yang digunakan yaitu NASNet, ResNet, } \\
\text { dan MobileNet. Hasil akurasi sebesar 93\%. }\end{array}$ \\
\hline 15 & {$[27]$} & $\begin{array}{l}\text { CNN, Fast R-CNN, R- } \\
\text { CNN, Faster R-CNN, } \\
\text { Tensorflow, Dataset } \\
\text { COCO, Deteksi Objek } \\
\text { underwater. }\end{array}$ & $\begin{array}{l}\text { Melakukan deteksi objek menggunakan metode } \\
\text { CNN, Fast R-CNN, R-CNN, dan Faster R- } \\
\text { CNN,. Hasil menunjukan bahwa metode Faster } \\
\text { R-CNN memiliki akurasi 96.21\% dengan } \\
\text { kecepatan yang lebih baik yaitu 0.2 detik. }\end{array}$ \\
\hline 16 & {$[28]$} & $\begin{array}{l}\text { DCNN, Discrete Wavelet } \\
\text { Transform (DWT), } \\
\text { GLCM, GRNN, Deteksi } \\
\text { Objek } \text { underwater. }\end{array}$ & $\begin{array}{l}\text { Melakukan deteksi objek menggunakan metode } \\
\text { klasifikasi DCNN, Pengskalaan citra } \\
\text { menggunakan DWT, dan ekstraksi fitur GLCM. } \\
\text { Hasil akurasi yang diperoleh sebesar 98,9\%. }\end{array}$ \\
\hline
\end{tabular}

\subsection{Machine Learning}

ML muncul sebagai metode pilihan dalam mengembangkan perangkat lunak untuk keperluan komputer visi, pengenalan suara, pemrosesan bahasa alami, kontrol robot, dan aplikasi lainnya. Para pengembang sistem AI mengakui bahwa jauh lebih mudah melatih suatu sistem dengan cara menunjukkannya contoh perilaku input-output yang diinginkan daripada memprogram secara manual dengan cara mengantisipasi respons yang diinginkan untuk semua kemungkinan input. Dampak dari penggunaan ML juga telah dirasakan secara luas di bidang ilmu komputer dan di berbagai industri yang berkaitan dengan masalah data intensif, seperti layanan konsumen, diagnosis kesalahan dalam sistem yang kompleks, dan kontrol rantai logistik [6]. ML memiliki efek besar pada banyak bidang teknologi dan sains, contohnya dalam aplikasi dalam identifikasi citra ikan seperti yang ditampilkan pada Gambar 1.
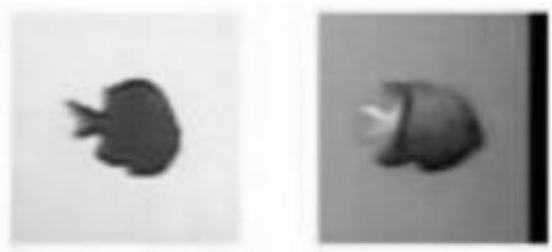

Klasifikasi spesies ikan [7]

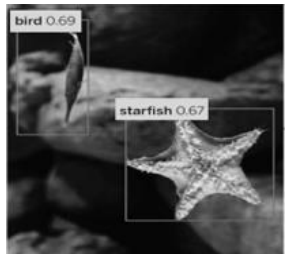

komputer visi [6]
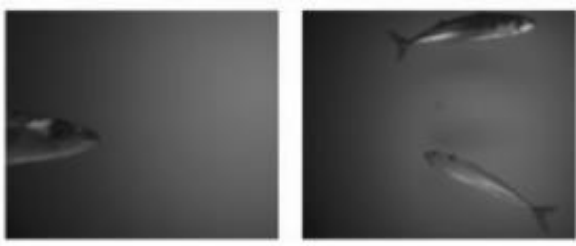

Identifikasi spesies ikan[8]

Gambar 1. Aplikasi ML dalam identifikasi citra ikan.

Tugas ML dikelompokkan ke dalam tiga kategori, yaitu (1) pembelajaran yang diawasi (supervised), (2) tidak diawasi (unsupervised), dan (3) diperkuat(reinforcement learning). Pembelajaran mesin yang diawasi membutuhkan pelatihan dengan data berlabel. Setiap data pelatihan berlabel terdiri dari nilai input dan nilai output target yang diinginkan. Algoritma pembelajaran yang diawasi menganalisis data pelatihan dan membuat fungsi yang disimpulkan, yang dapat digunakan untuk memetakan nilai-nilai baru. Dalam teknik pembelajaran mesin tanpa pengawasan, wawasan tersembunyi diambil dari kumpulan data yang tidak diberi label, misalnya, analisis klaster. Kategori ketiga, pembelajaran penguatan memungkinkan mesin mempelajari perilakunya dari umpan balik yang diterima melalui interaksi dengan lingkungan eksternal [4]. Dari sudut pandang pemrosesan data, teknik pembelajaran yang diawasi dan tidak

IJEIS Vol. 10, No. 2, October 2020 : $179-188$ 
diawasi lebih disukai untuk analisis data dan teknik penguatan lebih disukai untuk masalah pengambilan keputusan.

\subsection{Tensorflow}

Framework Tensorflow dikembangkan oleh Google Brain Team pada tahun 2015 untuk perhitungan numerik, dan sekarang banyak digunakan oleh perusahaan besar untuk pengembangan aplikasi AI, seperti klasifikasi citra, penyematan kata, dan pengembangan chatbot [9]. Tensorflow menyediakan antarmuka yang dapat mengekspresikan algoritma ML dan aplikasi untuk mengeksekusi algoritma [10]. Tensorflow mendukung pemodelan Recurrent Neural Network (RNN), Restricted Boltzmann Machine (RBM), Convolutional Neural Network dan Dynamic Bayesian Network (DBN), serta eksekusi paralel [10]. Nama Tensorflow didasarkan pada bagaimana tensor di seluruh jaringan. Tensor merupakan jenis array multidimensi[5].

\subsection{Klasifikasi Citra Ikan}

Klasifikasi citra ikan merupakan tugas yang sulit karena ada begitu banyak variasi bahkan dalam kelas citra ikan yang sama. Oleh sebab itu diperlukan metodologi yang tepat untuk melakukan pengembangan ini. Adapun metodologi yang ditawarkan dalam makalah ini dapat dilihat pada Gambar 2.

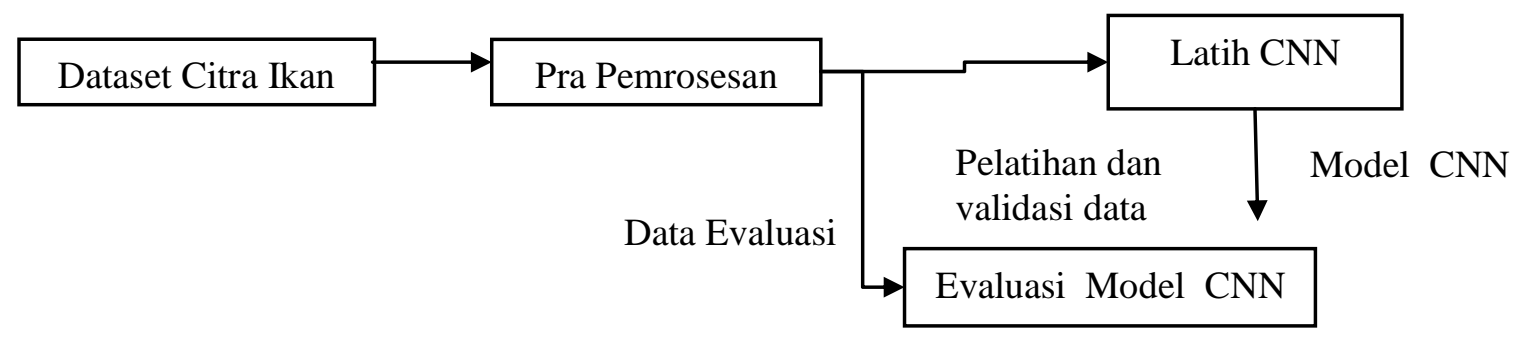

Gambar 2. Metodologi Klasifikasi Citra Ikan

Metodologi tersebut hasil modifikasi dari metodologi yang dibuat oleh Islam dkk. [11]. Pra pemrosesan citra digunakan untuk mengurangi kompleksitas dan meningkatkan akurasi. Dalam Pra pemrosesan citra dilakukan banyak hal seperti mengubah ukuran semua citra (misalkan menjadi $224 * 224 * 3$ ) untuk pelatihan, validasi, dan evaluasi. Pra pemrosesan citra ini memastikan bahwa hanya struktur yang berguna dan fitur citra yang dimasukkan ke dalam algoritma pembelajaran.

Secara umum terdapat 3 tahapan, yaitu pelatihan, validasi dan evaluasi. Pada tahapan pelatihan dilakukan pembentukan model $\mathrm{CNN}$; lalu ditahapan validasi, model tersebut divalidasi apakah sudah berjalan dengan benar agar memperoleh model CNN yang baik, dan tahapan evaluasi digunakan untuk mengetahui kemampuan model CNN dalam klasifikasi citra ikan lahan basah. Aksitektur yang ditawarkan untuk klasifikasi citra ikan lahan basah menggunakan Tensorflow ditunjukkan oleh Gambar 3. Model Tensorflow yang dipilih adalah MobileNet karena lebih optimal dibandingkan Inception v3.

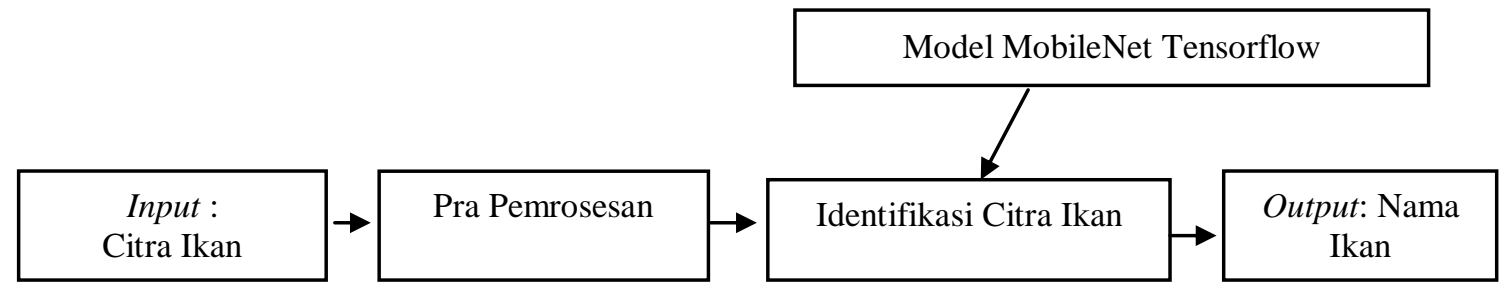

Gambar 3. Arsitektur Klasifikasi Citra Ikan Menggunakan Tensowflow 


\section{KESIMPULAN}

Berdasarkan pembahasan di atas, diketahui bahwa Tensorflow telah menyediakan beberapa model diantaranya Inception-v3 \& MobileNets yang dapat digunakan untuk klasifikasi citra. Model MobileNets memiliki keunggulan dapat mengoptimalkan waktu dan ruang dibandingkan Inception-v3, namun dalam hal akurasi model Inception-v3 lebih unggul. Pemodelan yang didukung oleh Tensorflow antara lain RCNN, CNN, RNN, RBM, dan DBN. Metode untuk pengurangan dimensi citra dapat menggunakan DWT, MDS, LLE, Isomap dan SE. Metode klasifikasi yang dapat digunakan untuk mengklasifikasikan citra ikan diantaranya adalah CNN, R-CNN, , DCNN, Fast R-CNN, kNN, PNN, Faster R-CNN, SVM, LR, RF, PCA dan KFA. Fungsi aktivasi ReLu menghasilkan akurasi terbesar daripada fungsi aktivasi lainnya (tanH, eLu, sigmoid, softplus, dan softsign). Supervised memiliki performa lebih baik dibandingkan unsupervised. Dataset yang dapat digunakan dalam Klasifikasi citra ikan diantaranya adalah MNIST, Oxford-I7, Oxford-102, LHI-Animal-Faces, Taiwan marine fish, KTH-Animal, NASNet, ResNet, dan MobileNet. Dari beberapa penelitian yang jelaskan diatas, belum ada ditemukan peneliti yang meneliti tentang pengembangan aplikasi identifikasi citra ikan kawasan lahan basah.

\section{SARAN}

Perlu menambahkan beberapa referensi terbaru terkait topik ini, walaupun dengan menggunakan librari, metode dan model yang telah dibahas diatas bisa digunakan dalam pengembangan aplikasi identifikasi citra ikan, khususnya ikan kawasan lahan basah.

\section{UCAPAN TERIMA KASIH}

Pekerjaan ini sebagian didukung oleh TIM Pendidikan Komputer FKIP Universitas Lambung Mangkurat.

\section{DAFTAR PUSTAKA}

[1] J. Akbar, POTENSI, PELUANG, DAN TANTANGAN PENGEMBANGAN PERIKANAN RAWA DI KALIMANTAN SELATAN, 1st ed. Banjarmasin: ULM Press. [Online]. Available: http://eprints.ulm.ac.id/2411/ [Accessed: 29-Oct- 2020].

[2] Hatta, "Lahan Basah, Kearifan Lokal, Dan Teknologi," Semin. Nas. ULM, pp. 7-13, 2016. [Online]. Available: http://eprints.ulm.ac.id/2646/ [Accessed: 29-Oct-2020].

[3] S. Bahri, "Jenis-Jenis Ikan Di Sungai Sambujur, Kalimantan Selatan," Bul. Tek. LITKAYASA Sumber Daya dan Penangkapan, vol. 7, no. 1, p. 13, 2016, doi: 10.15578/btl.7.1.2009.13-16. [Online]. Available: http://ejournal-balitbang.kkp.go.id /index.php/btl/article/view/2507 [Accessed: 29-Oct-2020].

[4] S. Athmaja, M. Hanumanthappa, and K. Vasantha, "A Survey of Big Data Analytics Using Machine Learning Algorithms," 2017 Int. Conf. Innov. Information, Embed. Commun. Syst., pp. 95-123, 2017, doi: 10.1109/ICIIECS.2017.8276028. [Online]. Available: https://ieeexplore.ieee.org/document/8276028/ [Accessed: 29-Oct-2020].

[5] A. Parvat, J. Chavan, S. Kadam, S. Dev, and V. Pathak, "A survey of deep-learning frameworks," Proc. Int. Conf. Inven. Syst. Control. ICISC 2017, pp. 1-7, 2017, doi: 10.1109/ICISC.2017.8068684. [Online]. Available: https://ieeexplore.iee.org /document/8068684 [Accessed: 29-Oct-2020].

[6] M. I. Jordan and T. M. Mitchell, "Machine learning: Trends, perspectives, and prospects," Science, vol. 349, no. 6245. pp. 255-260, 2015, doi: 10.1126/science .aaa8415. [Online]. Available: https://science.sciencemag.org/content/349/6245/255. [Accessed: 29-Oct-2020].

[7] D. Rathi, S. Jain, and S. Indu, "Underwater Fish Species Classification using

IJEIS Vol. 10, No. 2, October 2020 : $179-188$ 
Convolutional Neural Network and Deep Learning," 2017 9th Int. Conf. Adv. Pattern Recognition, ICAPR 2017, pp. 344-349, 2018, doi: 10.1109/ICAPR.2017.8593044. [Online]. Available: https://arxiv.org/abs/1805.10106 [Accessed: 29-Oct-2020].

[8] V. Allken, N. O. Handegard, S. Rosen, T. Schreyeck, T. Mahiout, and K. Malde, "Fish species identification using a convolutional neural network trained on synthetic data," ICES J. Mar. Sci., vol. 76, no. 1, pp. 342-349, 2019, doi: 10.1093/icesjms/fsy147. [Online]. Available: https://academic.oup.com/icesjms/article/76/1/342/5137114 [Accessed: 29-Oct-2020].

[9] T. P. Pereira Padilha and L. E. Alves de Lucena, "A Systematic Review About Use of TensorFlow for Image Classification and Word Embedding in the Brazilian Context," Acad. J. Comput. Eng. Appl. Math., vol. 1, no. 2, pp. 24-27, 2020, doi: 10.20873 /uft.2675-3588.2020.v1n2.p24-27. [Online]. Available: https://sistemas.uft.edu.br/ periodicos/index.php/AJCEAM/article/view/9466 [Accessed: 29-Oct-2020].

[10] M. Abadi et al., "TensorFlow: A System for Large-Scale Machine Learning This paper is included in the Proceedings of the TensorFlow: A system for large-scale machine learning," 12th USENIX Conf. Oper. Syst. Des. Implement., pp. 272-283, 2016, [Online]. Available: https://www.usenix.org/conference/osdi16/technical-sessions/presentation /abadi. [Accessed: 29-Oct-2020].

[11] M. T. Islam, B. M. N. Karim Siddique, S. Rahman, and T. Jabid, "Food Image Classification with Convolutional Neural Network," 2018 Int. Conf. Intell. Informatics Biomed. Sci. ICIIBMS 2018, vol. 3, pp. 257-262, 2018, doi: 10.1109/ICIIBMS .2018.8550005. [Online]. Available: https://ieeexplore.ieee.org/document/ 8550005 [Accessed: 29-Oct-2020].

[12] J. W. Gikandi, D. Morrow, and N. E. Davis, "Online formative assessment in higher education: A review of the literature," Comput. Educ., vol. 57, no. 4, pp. 2333-2351, 2011, doi: 10.1016/j.compedu.2011.06.004. [Online]. Available: http://dx.doi.org /10.1016/j.compedu.2011.06.004 [Accessed: 29-Oct-2020].

[13] L. Yuan, Z. Qu, Y. Zhao, H. Zhang, and Q. Nian, "A convolutional neural network based on TensorFlow for face recognition," Proc. 2017 IEEE 2nd Adv. Inf. Technol. Electron. Autom. Control Conf. IAEAC 2017, pp. 525-529, 2017, doi: 10.1109/IAEAC.2017 .8054070. [Online]. Available: https://ieeexplore.ieee.org/document/ 8054070 [Accessed: 1-aug-2020].

[14] D. Mulfari, A. Longo Minnolo, and A. Puliafito, "Building tensor flow applications in smart city scenarios," 2017 IEEE Int. Conf. Smart Comput. SMARTCOMP 2017, 2017, doi: 10.1109/SMARTCOMP.2017.7946991. [Online]. Available: https://ieeexplore .ieee.org/ document/7946991 [Accessed: 1-aug-2020].

[15] F. Ertam, "Data classification with deep learning using tensorflow," 2nd Int. Conf. Comput. Sci. Eng. UBMK 2017, pp. 755-758, 2017, doi: 10.1109/UBMK.2017.8093521. [Online].Available:https://ieeexplore.ieee.org/document/8093521 [Accessed:1-aug-20].

[16] X. Xia, C. Xu, and B. Nan, "Inception-v3 for flower classification," 2017 2nd Int. Conf. Image, Vis. Comput. ICIVC 2017, pp. 783-787, 2017, doi: 10.1109/ICIVC.2017 .7984661.[Online].Available:https://ieeexplore.ieee.org/document/7984661[Accessed:1aug-2020].

[17] N. R. Gavai, Y. A. Jakhade, S. A. Tribhuvan, and R. Bhattad, "MobileNets for flower classification using TensorFlow," 2017 Int. Conf. Big Data, IoT Data Sci. BID 2017, vol. 2018-Janua, pp. 154-158, 2018, doi: 10.1109/BID.2017.8336590. [Online]. Available: https://ieeexplore.ieee.org/document/8336590 [Accessed: 1-aug-2020].

[18] Z. Cao, J. C. Principe, B. Ouyang, F. Dalgleish, and A. Vuorenkoski, "Marine animal classification using combined CNN and hand-designed image features," pp. 1-6, 2017, doi: 10.23919/oceans.2015.7404375. [Online]. Available: https://ieeexplore.iee.org /document/7404375 [Accessed: 1-aug-2020].

[19] Y. H. S. Kumar, N. Manohar, and H. K. Chethan, "Animal classification system: A block based approach," Procedia Comput. Sci., vol. 45, no. C, pp. 336-343, 2015, doi: 
10.1016/j.procs.2015.03.156. [Online]. Available: https://www.sciencedirect.com /science/article /pii/S1877050915003920 [Accessed: 1-aug-2020].

[20] S. Taheri and Ö. Toygar, "Animal classification using facial images with score-level fusion," IET Comput. Vis., vol. 12, no. 5, pp. 679-685, 2018, doi: 10.1049/ietcvi.2017.0079. [Online]. Available: https://ieeexplore.ieee.org/document/8418325 [Accessed: 1-aug-2020].

[21] A. Faaeq, "Image Classification using Manifold Learning Based Non-Linear Dimensionality Reduction," 2018. [Online]. Available: https://ieeexplore.ieee .org/document /8404441 [Accessed: 1-aug-2020].

[22] E. Dandil and R. Polattimur, "PCA-Based Animal Classification System," in ISMSIT 2018 - 2nd International Symposium on Multidisciplinary Studies and Innovative Technologies, Proceedings, 2018, pp. 1-5, doi: 10.1109/ISMSIT.2018.8567256. [Online]. Available:https://ieeexplore.ieee.org/document/8567256/[Accessed:1-aug-20].

[23] N. Manohar, Y. H. S. Kumar, and G. H. Kumar, "Supervised and unsupervised learning in animal classification," 2016 Int. Conf. Adv. Comput. Commun. Informatics, ICACCI 2016, pp. 156-161, 2016, doi: 10.1109/ICACCI.2016.7732040. [Online]. Available: https://ieeexplore.ieee.org/document/7732040/ [Accessed: 1-aug-2020].

[24] A. Gomez Villa, A. Salazar, and F. Vargas, "Towards automatic wild animal monitoring: Identification of animal species in camera-trap images using very deep convolutional neural networks," Ecol. Inform., vol. 41, pp. 24-32, 2017, doi: 10.1016/j.ecoinf.2017 .07.004. [Online]. Available: https://www.sciencedirect.com /science/article/abs/pii/S1574954116302047 [Accessed: 1-aug-2020].

[25] L. Bloch et al., "Combination of image and location information for snake species identification using object detection and EfficientNets Combination of image and location information for snake species identification using object detection and EfficientNets FHDO Biomedical," Conf. Labs Eval. Forum, vol. 2696, 2020, [Online]. Available: http://ceur-ws.org/Vol-2696/paper_201.pdf. [Accessed: 1-aug-2020].

[26] G. G. Monkman, K. Hyder, M. J. Kaiser, and F. P. Vidal, "Using machine vision to estimate fish length from images using regional convolutional neural networks," Methods Ecol. Evol., vol. 10, no. 12, pp. 2045-2056, 2019, doi: 10.1111/2041210X.13282. [Online]. Available: https://research.bangor.ac.uk/portal/files/24990787 /fiducial_machine_vision_mee_r3.pdf [Accessed: 29-Oct-2020].

[27] S. Mahavarkar,Avinash; Kadwadkar, Ritika; Maurya, Sneha; Raveendran, "Underwater Object Detection using Tensorflow Avinash," ITM Web Conf., vol. 8, no. 5, pp. 20912095, 2020, doi: 10.22214/ijraset.2020.5344. [Online]. Available: https://www.itmconferences.org/articles/itmconf/abs/2020/02/itmconf_icacc2020_03037/itmconf_icacc2 020_03037.html. [Accessed: 29-Oct-2020].

[28] V. Karthikeyan, K. Raj Kumar, D. Vijay, and S. Aravind, "Underwater Object Detection," Int. J. Res. Appl. Sci. Eng. Technol., vol. 8, no. V, pp. 2091-2095, 2020, doi: http://doi.org/10.22214/ijraset.2020.5344. [Online]. Available: http://www.ijraset.com /fileserve.php?FID=28719. [Accessed: 29-Oct-2020]. 